\title{
Evropska študijska mobilnost in karierni načrti mladih
}

\author{
Elena Nacevska, Danica Fink Hafner, Barbara Brečko, Tanja Oblak Črnič
}

\begin{abstract}
Uvod
Prispevek obravnava evropsko študijsko mobilnost kot specifično obliko mobilnosti mladih, ki sooblikuje tudi njihove karierne načrte. Kadar karierni načrti vključujejo tudi mednarodno komponento, lahko predstavljajo pomembno spodbudo za mednarodno študijsko mobilnost in vplivajo na karierne poti ter poklicne preference mladih tako, da jih internacionalizirajo. Različne študije so že poudarile, da evropska študijska mobilnost prispeva k oblikovanju evropske identitete in makrodružbene formacije (gl. npr. Lesjak in Anussornnitisarn, 2017; Powell in Finger, 2013; Teichler, Ferencz in Wachter, 2011; Ifversen, 2000; Bagnoli, 2009; Genov, 2014; Golob, 2017). K tem ugotovitvam pa v tukajšnji razpravi dodajamo, da mednarodno študijsko mobilnost sooblikujejo tudi drugi dejavniki, kot so denimo odraščanje in osamosvajanje mladih (Arnett, 2004; Thomson in Taylor, 2005; Golob, 2017), imaginacijske izkušnje mladih v nacionalnem okolju, njihova izobrazba, delovne izkušnje, družbeno-ekonomske razmere in spol (Kogan in Unt, 2006; Kelly, McGuinness, O‘Connell, 2012), razredni in družbeni položaj (Lehmann, 2004), individualizacija in neugodne razmere za zaposlovanje doma (kot npr. v okoliščnah finančne krize) (Bauer in Kreuz, 2015).

Glavni cilj prispevka je tako ugotoviti, kaj vpliva na karierno načrtovanje mladih. Prispevek se podrobneje osredotoča na dve raziskovalni vprašanji: prvič, kaj mlade sploh spodbuja k temu, da se odločijo za študijsko
\end{abstract}


izmenjavo v tujini, in drugič, kaj jih od študijske mobilnosti znotraj Evrope morda odvrača. $Z$ odgovori na navedena vprašanja želimo identificirati morebitne ovire, ki nekatere skupine mladih destimulirajo na njihovi karierni poti v tujino, pa tudi ugotoviti, kakšno vlogo ima študijski program Erasmus+ pri načrtovanju zaposlitvenih karier mladih.

Osrednja teza tega prispevka je, da se karierni načrti mladih znotraj relativno homogene populacije diferencirajo in da so odvisni od mnogih dejavnikov. To pomeni, da so karierni načrti sicer lahko odraz individualnih želja in izbir, a so hkrati odvisni tudi od specifičnih družbenih, socialnih in kulturnih ozadij, v katerih se te izbire sploh lahko oblikujejo.

$\mathrm{V}$ prispevku predstavljamo ključne ugotovitve raziskave, ki je bila izvedena jeseni 2018 na populaciji študentov prve in druge stopnje Fakultete za družbene vede Univerze v Ljubljani (FDV) ter študentov, ki so prišli na mednarodno študijsko izmenjavo na FDV. Podatki so bili zbrani s spletnim anketiranjem, ki je potekalo od 7. 11. 2018 do 19. 12. 2018.

$\mathrm{V}$ prispevku najprej predstavimo podrobnejši pregled literature in javnopolitičnih dokumentov o dejavnikih študijske mobilnosti. V empiričnem delu predstavimo rezultate kvantitativne analize podatkov raziskave med študenti FDV, v zaključku pa empirične ugotovitve primerjamo $\mathrm{z}$ ugotovitvami predhodnih primerljivih raziskav.

\section{Strukturni in individualni dejavniki študijske mobilnosti}

\section{Ugotovitve znanstvene literature}

$\mathrm{Na}$ prelomu tisočletja so raziskovalci ugotavljali, da sodobni tehnološki razvoj in družbene spremembe, še posebej erozija družbenih spon, omogočajo večjemu številu mladih po vsej Evropi, da v življenjskem obdobju oblikovanja identitete in osebnega razvoja dlje časa preživijo izven svojega matičnega okolja (Arnett, 2004). A izkazalo se je, da je mobilnost mladih precej odvisna od različnih dejavnikov, predvsem od njihove izobrazbe, izkušenj, družbeno-ekonomskega oz. socialnega položaja in spola (Kondakci et al., 2018; Kelly, McGuinness, O‘Connell, 2012; Kogan in Unt, 2006).

Souto-Otero (2008) sta opozorila na to, da so študentje menili, da je bila štipendija, ki so jo prejeli, premajhna, in na to, da je stopnja izobrazbe staršev pomemben dejavnik udeležbe mladih v programu Erasmus+ (sodelovalo je namreč več študentov, katerih starši so zaključili visokošolsko izobrazbo). Van Bouwel in Veugelers (2013) sta ugotovila, da množičnost in usmeritev študentskih tokov pojasnjujeta kakovost visokošolskega siste- 
ma države prejemnice in pomanjkanje možnosti za izobraževanje v domači državi.

Zelo pomembne pri mobilnosti mladih so tudi strukturne posebnosti, kot so zahteve po delovni sili, nacionalne politike zaposlovanja, specifike političnega režima (Barry, 2010; Bynner, 2005). Po mnenju nekaterih avtorjev sta ključna dejavnika za omenjeno mobilnost razredni in socialni položaj v družbi (Lehmann, 2004), nanjo pa močno vplivajo tudi dostop do globalnih informacij (Kelly, 1999) in spodbude, ki jih ponujajo režimi/sistemi socialnega varstva (Schels, 2013). Nadalje so študijska mobilnost in bodoče poklicne kariere odvisne od posebnih institucionalnih okolij ter izobraževalnih sistemov in dostopa do trga dela (Kogan in Unt, 2006; Hannan in dr., 1997).

Poleg strukturnih okoliščin pa je obseg študijske mobilnosti lahko tudi rezultat povsem individualnih preferenc. Povezan je z osamosvajanjem in graditvijo individualne avtonomije. Študijska mobilnost namreč ne pomeni le prehoda meje $\mathrm{v}$ fizičnem smislu, temveč vsaj do neke mere pomeni tudi ločitev od skupnosti v simbolnem, fizičnem in emocionalnem smislu, vključevanje v drugačno družbeno-kulturno okolje (Golob, 2017). Pred odločitvijo za družino, zaposlitev in preostale vloge odraslega posameznika ima torej mobilnost pomembno vlogo v materialnih in simbolnih praksah, ki označujejo prehod iz adolescence v odraslost (Thomson in Taylor, 2005). Bagnoli (2009), denimo, ugotavlja, da si mladi s potovanji pridobivajo nove izkušnje in povečujejo individualni nadzor nad lastnim življenjem ter na ta način spreminjajo scenarije konstrukcije osebnosti.

Raziskave opozarjajo tudi na emocionalne in kulturne ovire, ki sooblikujejo evropsko mobilnost mladih (Golob, 2017). Pri tem ne gre le za to, da se posameznik sooča $z$ emocionalnimi izzivi, povezanimi s podporo mobilnosti doma in s slovesom od bližnjih ter pričakovanji glede življenjskih sprememb, temveč tudi z jezikovnimi ovirami in družbenimi semantičnimi razlikami.

V celoti gledano, se negativni dejavniki odločanja za študij v tujini akumulirajo pri študentih iz nižjih socialnih slojev, kar nakazuje potrebo po nacionalnih mehanizmih spodbujanja mobilnosti.

\section{Ugotovitve javnopolitičnih dokumentov}

Javnopolitični dokumenti Evropske unije govorijo o študijski mobilnosti zelo pozitivno. Študijska mobilnost je ocenjena kot pomemben sprožilec sprememb, modernizacije in višje kakovosti na vseh področjih življenja, saj 
spodbuja mreženja in izmenjave med institucijami (EK, 20o8; EK, 2019b) spodbuja učenje jezikov kot sredstva za izgradnjo evropske integracije in državljanstva ter tudi za delovanje trga (EK, 2008 in EK, 2019a). Komisija EU promovira politike mobilnosti in sodelovanja $\mathrm{v}$ izobraževanju kot sestavine enotne organizacijske strukture dodiplomskega-magistrskega-doktorskega študija in boljšega zagotavljanja kakovosti (EK, 2020a), uveljavljajo pa se tudi priporočila Sveta Evrope, naj se spodbuja avtomatično vzajemno priznavanje diplom in spričeval ter izidov iz učnih obdobij v tujini (EK, 2018 - COM(2018) 270), ideja evropske študentske izkaznice, ki omogoča boljšo izmenjavo informacij o študentih, ter ideja oblikovanja koalicij evropskih univerz za povečanje konkurenčnosti, kakovosti in odličnosti v poučevanju, raziskavah in inovacijah (EK, 2020a).

Program Erasmus+ je ocenjen kot ključni dejavnik internacionalizacije in nekoliko tudi evropeizacije visokošolskih izobraževalnih sistemov v EU (EK, 2019b). Po podatkih Evropske komisije več kot 70 \% nekdanjih študentk in študentov, ki so bili vključeni v program Erasmus+, navaja, da po vrnitvi iz tujine bolje vedo, kakšno poklicno pot si želijo, 80 \% študentk in študentov Erasmus+ pa, da jim je izkušnja v tujini pomagala najti prvo zaposlitev (EK, 2019b; EK, 2015).

Pri tem ne gre spregledati, da ima politika učne mobilnosti dva cilja: 1. okrepiti konkurenčnost Evrope in graditi družbo, ki bo temeljila na znanju; in 2. poglobiti občutek evropske identitete in državljanstva med mladimi. Zato ni naključno, da Evropska komisija v poročilu posebej poudarja, da $72 \%$ študentov študijske mobilnosti ne povezuje le s povečanjem svojih tehničnih spretnosti, s krepitvijo samozavesti in sposobnosti doseganja ciljev ter svojih zaposlitvenih možnosti, temveč tudi s povečanjem medosebnih in medkulturnih spretnosti in kompetenc ter socialne in kulturni odprtosti (EK, 2019b).

Programa Erasmus in Erasmus+, ki sta bistveno prispevala k študijski mobilnosti, sta se hitro uveljavila in dosegla široko prepoznavnost (EK, 2019b). Od leta 1987 do študijskega leta 2019 je v izmenjavi študentske mobilnosti Erasmus in Erasmus+ sodelovalo več kot 3 milijone študentov (EK, 2019c; Bauer in Kreuz, 2015). Trenutni program Erasmus +, ki je potekal od leta 2014 do 2020, je podpiral skoraj 800.000 ljudi pri študiju, usposabljanju ali delu v tujini, kar je za 10 \% več kot v letu 2016. V študijskem letu 2016/2017 (EK, 2017c) je ta program omogočil izobraževanje ali usposabljanje v tujini več kot 400.000 visokošolskim študentom, pripravnikom in vi- 
sokošolskemu osebju, oziroma okoli 34.000 študentov je prejelo nepovratna sredstva za odhod v partnerske države.

Mednarodnoprimerjalni pogled pa vendarle pokaže tudi meje evropske (študijske) mobilnosti. Glede na Poročilo o mobilnosti 2019 (EK, 2019a) je bilo leta 2018 v EU 17,6 milijona preseljencev, med katerimi je bilo 12,9 milijona delovno sposobnih oseb (20-64 let), kar pomeni, da je 4,2 \% delovno sposobnega prebivalstva EU delalo v drugi državi EU. Približno polovico mobilne delovne sile znotraj EU gostita Nemčija in Združeno kraljestvo, največji delež delovne sile glede na prebivalstvo posamezne države pa prihaja iz Litve, Romunije in Hrvaške (EK, 2019a). Poročilo tudi kaže, da polovica preseljencev ostaja $v$ gostiteljski državi za obdobje enega do štirih let. V primerjavi z ZDA, kjer tretjina državljanov (32 \%) živi zunaj države, v kateri so se rodili, je to še vedno malo.

Evropski javnopolitični dokumenti opozarjajo tudi na družbeno-ekonomske razlike kot dejavnik študijske mobilnosti (Eurostudent VI Short Report (2016-2018); Eurostudent VI Database; Eurostudent VI - Synopsis of Indicators (2016-2018). Več je namreč preseljevanja $\mathrm{v}$ države članice $\mathrm{z}$ liberalnimi ali socialdemokratskimi režimi in v države z bolj razvitim socialnim varstvom, saj imajo študenti v njih boljše zaposlitvene priložnosti. Po zadnjem poročilu Eurostudent VI - Overview and selected findings (20162018) (Gril, Bijuklič in Autor, 2018; EK, 2020c) je 51 \% študentov v času izmenjave opravljalo tudi delo za plačilo.

\section{Dejavniki študijske mobilnosti in karierne poti med študenti FDV}

\section{Cilji, metoda raziskave in zbiranje podatkov}

Anketni vprašalnik je vključeval več različnih sklopov: spraševali smo o odnosu mladih do EU in njihovih vizij Evrope v prihodnosti; o njihovi informiranosti in participaciji v EU; o karierni mobilnosti in vrednotah. V tem prispevku se osredotočamo na vprašanje, kako o svoji prihodnosti razmišljajo mladi in kako so različne vizije o njihovi prihodnosti odvisne od izkušenj s študijsko mobilnostjo in njihovo karierno potjo ali pa pogojene z nji$m i$. V tem sklopu so bila za nas ključna naslednja vprašanja: Ali so/bodo študenti opravili študij na tuji univerzi? Kateri so glavni razlogi za njihovo mobilnost? Zakaj mladi sploh odidejo $v$ tujino oz. kaj jih od študijske mobilnosti znotraj Evrope odvrača? Kakšno vlogo ima pri evropski integraciji študijski program Erasmus+ in kaj prinaša v luči zaposlitvenih karier mladih? 
$\mathrm{Z}$ anketo smo želeli zajeti čim več študentov FDV, tako domačih kot tudi študentov na izmenjavi (Erasmus+). V študijskem letu 2018/19 je bilo na prvo stopnjo študija vpisanih 1425 študentk in študentov, na drugo stopnjo pa 471 študentk in študentov, torej skupno 1896 vpisanih. V prvem semestru je bilo vpisanih 135 tujih študentov na izmenjavi (Mednarodna pisarna, FDV, 2018). Spletna anketa je bila pripravljena $\mathrm{v}$ angleškem in slovenskem jeziku, anketiranci pa so lahko izbirali, v katerem jeziku želijo odgovarjati. Anketiranje smo pričeli 7. 11. 2018, zaključili pa 19. 12. 2018. Anketo je vsaj delno izpolnilo 208 slovenskih študentov in 61 tujih, kar pomeni, da je odgovarjalo $11 \%$ vseh vpisanih slovenskih študentov in $45 \%$ vseh študentov na izmenjavi.

\section{Rezultati}

\section{Izkušnje, ovire in spodbujanje študijske mobilnosti}

Izmenjava Erasmus+ je pomemben korak k študijski mobilnosti, saj mladi tako spoznavajo študijske razmere zunaj domačega okolja. V tem kontekstu je zanimivo, da je skoraj 40 \% vprašanih del študija že opravilo v tujini $^{\mathrm{I}}$, dodatnih $35 \%$ jih to še namerava, medtem ko dobra četrtina vprašanih $(26 \%) v$ tujini še ni bila in $v$ tujino niti ne namerava oditi.

Študentom z izkušnjo študija v tujini smo zastavili vprašanje o razlogih zanj (glejte Tabelo 7) ${ }^{2}$. Študenti so odgovarjali, v kolikšni meri so navedeni razlogi vplivali na njihovo odločitev za študij v tujini (ali sploh niso vplivali, so malo vplivali, niti niso vplivali niti ne vplivali, so precej vplivali, so zelo vplivali). Podatki kažejo, da je med najpomembnejše razloge mogoče šteti spoznavanje drugih kultur $(4,5)$, vzpostavljanje medosebnih stikov in mednarodnih povezav $(4,4)$ ter izboljšanje znanja tujega jezika $(4,3)$. Zanimivo je, da tudi tisti študenti, ki se študija $v$ tujini šele nameravajo udeležiti ${ }^{3}$ za to navajajo skoraj enake ključne razloge: izboljšanje znanja tujega jezika $(4,6)$ in pridobivanje izkušenj v zvezi z drugimi kulturami $(4,4)$.

$1 \quad$ Vprašanje se je glasilo: Ali ste del svojega študija opravili na tuji univerzi? a) Da. b) $\mathrm{Ne}$ še, ampak nameravam. c) Ne, nisem in niti ne nameravam.

2 Q29 - V kolikšni meri so naslednji razlogi vplivali na vašo odločitev, da ste del študija opravili v tujini? a) Izboljšanje zaposlitvenih možnosti doma. b) Izboljšanje zaposlitvenih možnosti v tujini. c) Izboljšanje znanja tujega jezika. d) Boljše razmere za študij in raziskovalno delo. e) Spoznavanje drugih kultur. f) Pridobitev izkušenj v zvezi z drugačnimi metodami poučevanja. g) Vzpostavljanje osebnih omrežij in mednarodnih povezav. h) Izkušnja samostojnega življenja. i) Drugo: 
Tabela 7: Razlogi za študijsko mobilnost

\begin{tabular}{lccc}
\hline & $\begin{array}{c}\text { Povprečna } \\
\text { vrednost }\end{array}$ & Std. odklon & N \\
\hline Izboljšanje zaposlitvenih možnosti doma & 3,32 & 1,37 & 71 \\
\hline Boljši pogoji za študij in raziskovalno delo & 3,63 & 1,27 & 73 \\
\hline Izboljšanje zaposlitvenih možnosti v tujini & 3,66 & 1,31 & 71 \\
\hline Pridobitev izkušenj z drugimi metodami poučevanja & 4,13 & 1,07 & 71 \\
\hline Izkušnja samostojnega življenja & 4,18 & 1,10 & 72 \\
\hline Izboljšanje znanja tujega jezika & 4,26 & 0,90 & 72 \\
\hline Vzpostavljanje osebnih omrežij in mednarodnih povezav & 4,35 & 0,92 & 71 \\
\hline Spoznavanje drugih kultur
\end{tabular}

Vir: Spletna anketa, FDV, 2018

Ugotavljamo, da so med študenti glede na to, ali že imajo izkušnje s študijsko mobilnostjo ali ne, ključne razlike. Pri raziskovanju odnosa med pričakovanimi kompetencami, potrebnimi za mobilnost, in socialnim ozadjem mladih smo identificirali morebitne ovire, ki nekatere skupine mladih destimulirajo na njihovi karierni poti.

Pri študentih brez izkušenj s študijsko mobilnostjo so med naštetimi ovirami najvišje ocenjene družinske obveznosti $(2,9)$ in prenizka štipendija za študij $(2,6)$, kar vsaj posredno kaže na pretežno socialne in materialne ovire pri uresničevanju tovrstnih možnosti, vendar so povprečne vrednosti povsod relativno nizke ${ }^{4}$.

Naslednja značilnost zajetega vzorca študentov je, da jih večina poleg študija opravlja tudi delo za plačilo. To nas lahko privede do sklepa, da je razlog za neodhod v tujino ali pa ovira, zaradi katere se za odhod v tujino

b) Izboljšanje znanja tujega jezika. c) Boljše razmere za študij in raziskovalno delo.

d) Pridobitev izkušenj v zvezi z drugimi kulturami.

4 Q28 - V kolikšni meri so naslednji razlogi vplivali na to, da dela študija niste opravili v tujini? a) Prenizka štipendija, namenjena za mobilnost. b) Pomanjkljivo znanje tujega jezika. c) Študentsko delo. d) Družinske obveznosti. e) Politične in društvene aktivnosti. f) Drugi razlogi: 


\section{Ali poleg študija tudi delate za plačilo?}

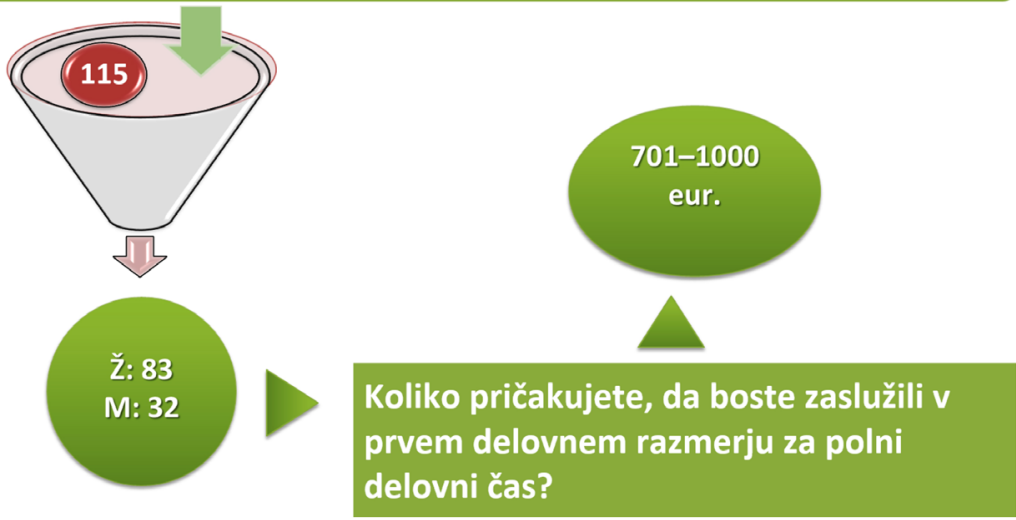

Slika 6: Študentsko delo

ne odločijo ${ }^{5}$, šibek družbeno-ekonomski status - takih respondentov je kar $65 \%$ vseh anketiranih.

\section{Karierne poti in razlike med domačijskim in kozmopolitskim tipom}

Rezultati statističnih analiz med drugim kažejo na dve podskupini znotraj vzorca študentov. Identificirali smo namreč t. i. »domačijski tip«, ki ga sestavljajo tisti, ki se za študijsko mobilnost niso odločili in se zanjo tudi v prihodnje ne nameravajo odločiti, ter »kozmopolitski tip«, ki je študijsko in tudi karierno mobilnejši. Pri raziskovalnih vprašanjih smo se osredotočili na morebiten obstoj dejavnikov (znotraj vzorca), ki kažejo na ključne razlike med tema dvema podskupinama. Domnevali smo namreč, da so karierni načrti mladih »domačijskega tipa« precej bolj odvisni od specifičnih ozadij, ki so ekonomsko in socialno determinirana. Tovrstnih ovir pri skupini mladih »kozmopolitskega tipa«, v luči njihove mobilnosti in kariernih poti, ne opažamo oziroma so te, vsaj sodeč po rezultatih, manj očitne.

Želja po študijski mobilnosti je izrazito povezana $\mathrm{z}$ iskanjem zaposlitvenih priložnosti pri kozmopolitskem tipu študentov. Ti si želijo osamosvojitve in neodvisnosti v luči iskanja zaposlitev v državah članicah EU in $\mathrm{v}$ tujini. Ugotovili smo določene razlike med študenti ( $\mathrm{v}$ skupini 


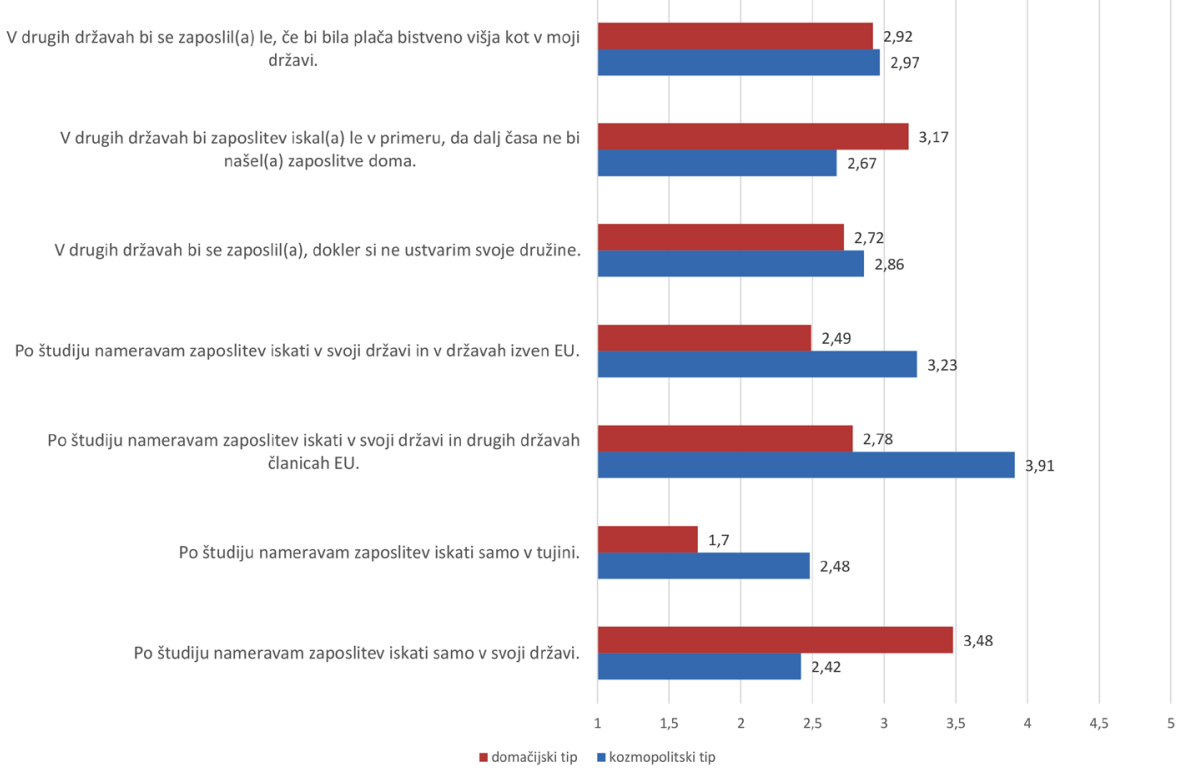

Slika 7: Iskanje zaposlitvenih priložnosti - ključne razlike med domačijskim in kozmopolitskim tipom mladih Vir: Spletna anketa, FDV, 2018

kozmopolitskega tipa), ki se bolj nagibajo $\mathrm{k}$ iskanju zaposlitve $\mathrm{v}$ EU in $\mathrm{v}$ tujini, $\mathrm{v}$ primerjavi $\mathrm{z}$ domačijskim tipom anketiranih študentov oziroma študentov, ki bi zaposlitev v tujini iskali le, če si dlje časa ne bi mogli zagotoviti zaposlitve doma. Tisti, ki so glede študijske mobilnosti že bolj izkušeni, so pokazali bistveno večjo odprtost za širše karierne priložnosti $\mathrm{v}$ tujini. Nasprotno pa se t. i. domačijski tip v veliki večini namerava zaposliti ${ }^{6}$ izključno v svoji državi, znotraj tega tipa tudi najmanj študentov načrtuje iskanje zaposlitve izključno v tujini. Podatki na Sliki 7 ravno na tej ravni kažejo najbolj očitne razlike med omenjenima skupinama. Če je torej kozmopolitski tip do zaposlitvenih možnosti zunaj doma izjemno odprt in temu naklonjen, velja za študente domačijskega tipa ravno obratno tujina je zanje možnost le v skrajnem primeru, če zaposlitve več časa ne bi uspeli dobiti doma.

6 Q35 - V kolikšni meri se strinjate oziroma se ne strinjate z naslednjimi trditvami? a) Po študiju nameravam zaposlitev iskati samo v svoji državi. b) Po študiju nameravam zaposlitev iskati samo v tujini. c) Po študiju nameravam zaposlitev iskati v svoji državi in v drugih državah članicah EU. d) Po študiju nameravam zaposlitev iskati v svoji državi in v državah izven EU. 
Pripravljenost za zaposlitev v tujini ${ }^{7}$ je pri domačijskem tipu še v največji meri odvisna od pričakovanega dohodka - največ teh študentov namreč meni, da bi se v tujini zaposlili le, če bi bila plača tam bistveno višja kot pa predvideni dohodek za delo doma, pri čemer se kažejo razlike tudi med spoloma (ženske: 34 \%; moški: 42 \%). Hkrati se jim zaposlovanje v tujini zdi bolj verjetno v obdobju, v katerem si še ne bodo ustvarili lastne družine, vendar je presenetljivo, da bi to na neodhod v tujino v večji meri vplivalo pri kozmopolitskem tipu. Golob (2017) je na podoben način pojasnila družbeni kontekst, $\mathrm{v}$ katerem se posameznik nahaja in ki deluje kot potencialni vzročni sprožilec konstitucije posameznikovega notranjega sveta in konstrukcije pomenov. Motivi za izmenjavo lahko izhajajo tudi iz nezavednih dispozicij posameznikovega habitusa, ki vplivajo na njegovo delovanje in aspiracije ter se oblikujejo v odnosu do družbenih polj (Golob, 2017).

\section{Odnos do EU in razlike v zaznavanju pomena jezikovnih kompetenc}

Pri obravnavi izmenjave je pomembno dejstvo, da shema Erasmusa, ki določa strukturne vidike obreda prehoda, ustreza potrebam tržne ekonomije, še posebej naraščajočim potrebam po specializiranih kvalifikacijah. V luči individualizirane družbe je med mladimi prisotna težnja po doseganju uspeha na podlagi individualnega truda, kar je povezano tudi z neoliberalnimi idejami atomizacije ekonomskega in političnega življenja (Genov, 2014). Študenti se, kar je pri opazovanju njihove izobraževalne poti očitno, soočajo z makrostrukturnimi učinki individualizacije. Učne načrte po bolonjskem sistemu sestavljajo številni izbirni moduli, pomembno vlogo pa igrajo strukturni dejavniki, kot so ekonomske, družbene in socialne razmere.

Mobilnost mladih se navezuje na njihov odnos do EU ter na njihov vpogled v globalne možnosti izmenjave in karierne priložnosti. Zanimivo je tudi, kakšen odnos imajo mladi do Evropske unije ter kakšne so pri tem razlike med domačijskim in kozmopolitskim tipom študentov. Raziskava med domačimi in tujimi študenti o njihovem odnosu do Evrope, o trenutnih predstavah mladih o EU in njihovih morebitnih vizijah razvoja $\mathrm{EU}^{8}$

7 Q50 - V kolikšni meri se strinjate oziroma ne strinjate z naslednjimi trditvami? a) V drugih državah bi se zaposlil(a), dokler si ne ustvarim svoje družine. b) V drugih državah bi zaposlitev iskal(a) le v primeru, da dalj časa ne bi našel(a) zaposlitve doma. c) V drugih državah bi se zaposlil(a) le, če bi bila plača bistveno višja kot v moji državi.

8 Q3 - V kolikšni meri se strinjate oziroma se ne strinjate s spodnjimi trditvami? a) Sem Evropejec/Evropejka. b) Ponosen(a) sem, da živim v Evropi. c) Čutim se kot del 


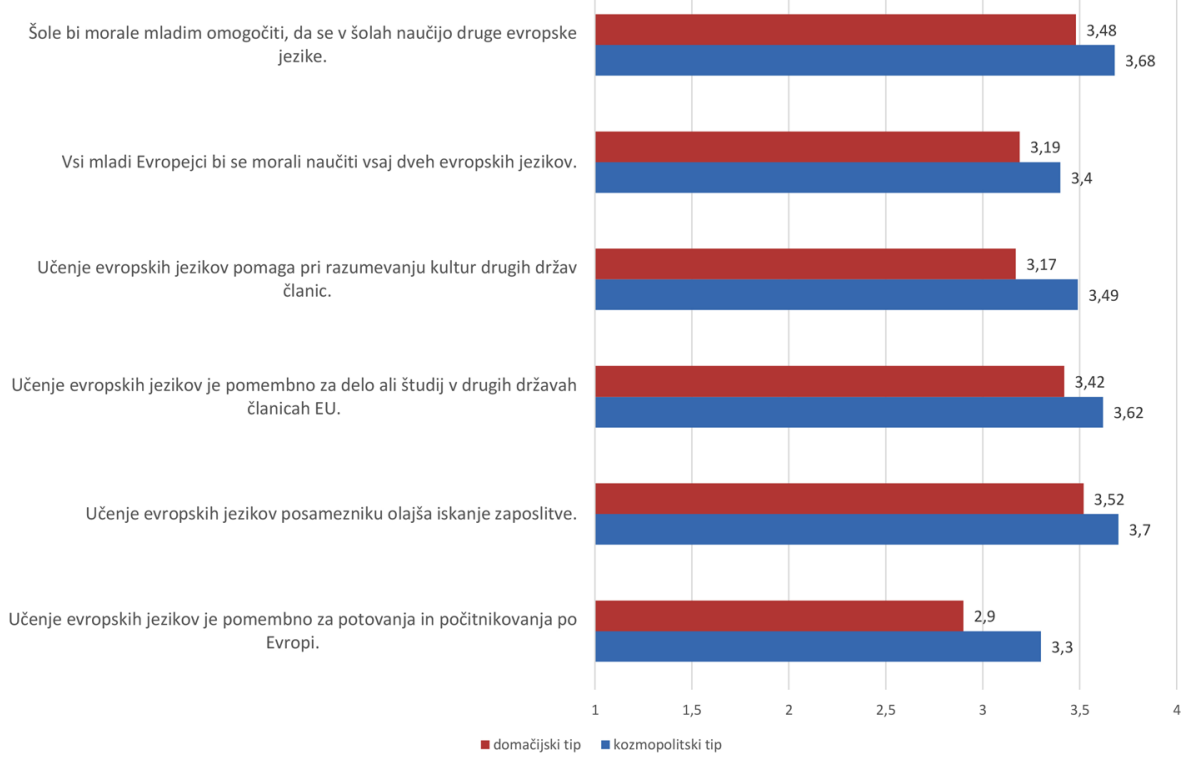

Slika 8: Učenje tujih jezikov

Vir: Spletna anketa, FDV, 2018

kaže, da je odnos večine vprašanih do EU bolj pozitiven (50 \%) oz. zelo pozitiven ( $8 \%$ ), da pa je dobra četrtina ( $27 \%)$ mladih do EU nevtralna. Trenutno predstavo, ki jo gojijo mladi o EU, smo skušali zajeti z naborom več pojmov, ki bi pokazali možen odnos mladih do EU. Izkaže se, da večina respondentov EU povezuje s pojmi, kot so »moderna $(76 \%)$, »demokratična« $(68 \%)$ in »usmerjena v prihodnost« (67 \%), kar kaže na pozitivne konotacije, ki jo ima EU za mlade.

Na drugi strani pa smo domnevali, da imata pri odločitvi za karierne poti pomembno vlogo učenje tujih jezikov in zaznava pomena jezikovnih kompetenc. Tudi v tem primeru opažamo razlike med domačijskim in kozmopolitskim tipom anketiranih študentov, vendar so te bistveno manjše.

Učenju tujih jezikov so študenti obeh skupin relativno zelo naklonje$\mathrm{ni}$, pri čemer študenti $\mathrm{z}$ izkušnjo študija $\mathrm{v}$ tujini temu prisojajo večjo pomembnost kot ostali, vendar ne moremo trditi, da študenti domačijskega tipa zanemarjajo pomen znanja tujih jezikov.

Evrope. d) Sebe vidim najprej kot državljana/državljanko Evrope in šele potem kot državljana/državljanko sveta. e) Več imam skupnega z drugimi ljudmi iz držav EU kot z ljudmi iz držav izven EU. f) Več imam skupnega z ljudmi iz moje države kot z ljudmi drugih narodov v Evropi. g) Čutim se globalnega državljana/državljanko. 


\section{Sklep}

Program Erasmus+ je postal pomemben del razvojne strategije EU do leta 2020 (Jones, 2017), ideja mobilnosti pa je postala pomembna tudi v širšem evropskem izobraževalnem prostoru (EK, 2017a, 2017b). Slovenske in mednarodne raziskave na področju študijske mobilnosti (Breznik in Đaković, 2016; Čelebič, 2008), pa tudi rezultati naše raziskave opozarjajo na mnogotere, še posebej družbeno-ekonomske razsežnosti študijske mobilnosti. Odhodna in vhodna mobilnost glede na velikost študentske populacije v vsaki državi je odvisna od ekonomskih, zgodovinskih, kulturnih in političnih dejavnikov (Breznik in Đaković, 2016; Böttcher et al., 2016). Na študijsko mobilnost vplivajo tudi višina štipendije, možnosti za namestitev in kakovost visokošolskega sistema. Pomemben dejavnik, ki vpliva na število tujih študentov, je jezik, v katerem poteka pedagoški proces (Čelebič, 2008), saj se študenti bolj odločajo za države, v katerih je učni jezik angleški (OECD, Education at a Glance 2006).

Za slovenske študente je lahko ovira za nevključitev v študijsko mobilnost predvsem financiranje študija. Čelebič (2008) opozarja, da je to ovira predvsem za posameznike in posameznice iz nižjih socialnih slojev. Dodaten finančni vir, poleg štipendije v okviru programa Erasmus, namreč pogosto predstavlja tudi finančni prispevek staršev, ki pa si ga lahko privoščijo družine $\mathrm{z}$ nadpovprečno visokim dohodkom. Zato je delež študentov iz družin z nadpovprečno visokim dohodkom precej višji kot pa delež tistih iz družin s podpovprečnim dohodkom (nadpovprečni: $36,6 \%$; podpovprečni: 14,9 \%; povprečni: 48,4\%) (Čelebič, 2008).

Rezultati v članku predstavljenih statističnih analiz naše raziskave so pokazali, da so možnosti mladih znotraj relativno homogenega vzorca diferencirane in vsaj delno odvisne od nekaterih strukturnih dejavnikov. Pomembni dejavniki, ki prispevajo k odločitvi študentov za mobilnost v okviru kariernih poti, so ekonomsko in socialno determinirani. Identificirali smo jih le delno, a vendar lahko rečemo, da so ovire za odhod v tujino tesno povezane predvsem $\mathrm{z}$ družinskimi obveznostmi študentov in s pomanjkanjem finančnih sredstev. Za poglobljeno pojasnitev tu zaznanih ekonomskih in socialnih ozadij bi bila sicer potrebna podrobnejša analiza zbranih podatkov, a omenjeno priča o pomembnih razlikah znotraj vzorca študentov. Nekateri med njimi se, strukturno gledano, že v izhodišču soočajo $\mathrm{z}$ manj spodbudnimi možnostmi za študijsko mobilnost. Skrb za družino, starše ali svojce in prenizek finančni okvir niso stvar osebnih izbir, temveč jih je treba nasloviti na ravni politik za spodbujanje študijske mobilnosti. 
Hkrati pa se zdi, da so karierni načrti vendarle vsaj do neke mere odraz individualnih želja in izbir. $V$ zvezi z raziskovalnimi vprašanji smo nadalje ugotovili, da imajo mladi o svoji prihodnosti različne vizije, ki so precej odvisne od njihovih izkušenj s študijsko mobilnostjo in z njihovo karierno potjo oziroma so pogojene $\mathrm{z}$ njimi. Rezultati statističnih analiz med drugim poudarjajo razlike med dvema podskupinama znotraj vzorca študentov, in sicer med »domačijskim tipom«, ki ga predstavljajo tisti, ki se za študijsko mobilnost niso odločili in se zanjo tudi v prihodnje ne nameravajo odločiti, in »kozmopolitskim tipom «, ki je študijsko in tudi karierno mobilnejši. Razlike med tema skupinama so še posebej razvidne v tem, kak pomen pripisujejo učenju jezikov in spoznavanju drugih kultur. Slednje govori $v$ prid tezi, da je multikulturnost pogojena tudi $z$ določenimi učnimi kompetencami in predznanji. Po drugi strani študijska mobilnost širi tudi siceršnje možnosti za karierne poti mladih, kar govori v prid tezi, da se s programom Erasmus+ bistveno povečuje tudi fizična mobilnost mladih, posledično pa mladi svojo predstavo o prihodnosti lažje umeščajo tudi onstran nacionalnih meja. Ravno z izrazito večjo odprtostjo do kariernih poti v tujini so se študenti, ki izkušnjo $s$ študijem $v$ tujini že imajo, izkazali za bistveno drugačne od študentov domačijskega tipa, ki ostajajo tudi v odnosu do lastnih vizij prihodnosti bolj navezani na dom in možnosti znotraj obstoječih nacionalnih meja. Zdi se, da je s tem delno povezana tudi njihova osebna vizija poteka lastnega družinskega življenja.

Omenjeni pozitivni učinek študijskih izmenjav (zaznaven pri eni skupini študentov) kaže jasno sporočilo, obenem pa opozarja tudi pomembno strukturno omejitev. Mladi »domačijskega tipa« so namreč manj prožni in manj mobilni predvsem zaradi specifičnih socialnih in ekonomskih ovir. To govori o pomembnih razkorakih pri karierni mobilnosti mladih, kolikor je o njej mogoče sklepati znotraj tega specifičnega namenskega vzorca. Naša raziskava ponuja še vrsto drugih dilem (vključno s spolnimi razlika$\mathrm{mi}$ ), ki bi jih veljalo nasloviti v prihodnje $\mathrm{z}$ dodatno analizo podatkov, že delni rezultati pa pričajo o potrebi po bolj poglobljenem raziskovanju razmer, v katerih živijo ravno tisti študenti, ki se za študijsko mobilnost težko ali neradi odločajo.

\section{Literatura}

Arnett, J. Jeffrey. Emerging Adulthood: The Winding Road from Late Teens through the Twenties. Oxford, New York: Oxford University Press, 2004. 
Bagnoli, Anna. „On 'An Introspective Journey’: Identities and Travel in Young People's Lives.“ European Societies, 11 (2009): 325-345.

Barry, Monika. "Youth transitions: From offending to desistance.« Journal of Youth Studies, 1 (2010): 121-136. doi.org/d4chrh.

Bauer, Thomas, in Alexandra Kreuz. »Erasmus and Ehea student mobility in times of the European Economic crisis. The situation of international teacher Training students in Austria." Journal of International Mobility, 2015/1, no. 3 (2015): 99-114. Dostop November 1, 2019. https://www.cairn. info/revue-journal-of-international-mobility-2015-1-page-99.htm.

Böttcher, Lucas in Nuno A. M. Araújo, Jan Nagler, José F. F. Mendes, Dirk Helbing, Hans J. Herrmann. »Gender gap in the Erasmus Mobility program." PLOS ONE 11/2 (2016): eo149514. https://doi.org/10.1371/ journal.pone.0149514.

Breznik, Kristijan in Goran Đaković. Erasmus student mobility flows the national-level social network analysis of Slovenia. International Journal of Innovation and Learning 20/2 (2016). DOI: 10.1504/ IJIL.2016.077843. Dostop Junij 14, 2020. https://www.inderscienceonline.com/doi/pdf/10.1504/IJIL.2016.077843, 12.6.2020.

Bynner, John. "Rethinking the youth phase of the life-course: The case for emerging adulthood? « Journal of Youth Studies, 4 (2005): 367-384. doi.org/fdp8hq.

Čelebič, Tanja. Mednarodna mobilnost študentov in pedagoškega osebja v terciarnem izobraževanju. Zbirka Delovni zvezki UMAR, 17/8 (2008). Ljubljana: Urad RS za makroekonomske analize in razvoj, 2008. Dostop Junij 29, 2020. https://www.umar.gov.si/fileadmin/ user_upload/publikacije/dz/2008/dzo8-o8-old.pdf.

Genov, Nikolai. »The Future of Individualization in Europe: Changing Configurations in Employment and Governance.« Eur J Futures Res, 2 (2014): 46. doi.org/10.1007/s40309-014-0046-5.

Golob, Tea. »Evropska študijska mobilnost kot sodobni obred prehoda.« Glasnik Slovenskega etnološkega društva, 57, št. 3/4 (2017): 75-84. http:// www.dlib.si/?URN=URN:NBN:SI:DOC-GVTCVLTY.

Gril, Alenka, Igor Bijuklič, Sabina Autor. EVROŠTUDENT VI 2016-2018, Socialni in ekonomski pogoji življenja študentov v Evropi. Nacionalno poročilo - Slovenija. Ljubljana: Pedagoški Inštitut. Dostop Junij 29, 2020. https://www.eurostudent.eu/download_files/documents/ EVROSTUDENT_VI_Porocilo_SLO.pdf. 
Hannan, Damian F., David Raffe, in Emer Smyth. „Cross-national research on school to work transitions: An analytical framework. In Youth transitons in Europe: Theories and evidence, ur. Patrick Werquin, Richard Breen in Jordi Planas, 409-442. Cereq: Marseille, 1997.

Ifversen, Jan. "Europe and European Culture - a Conceptual Analysis." European Societies, 4 (2002): 1-26. DOI: 10.1080/14616690220130973.

Jones, Hywel Cery. »Celebrating 30 years of the Erasmus programme.« European Journal of Education 52/4 (2017): 558-562. https://doi. org/10.1111/ejed.12251.

Kelly, Elish, Seamus McGuinness in Philip J. O‘Connell. »Transitions to long-term unemployment risk among young people: Evidence from Ireland." Journal of Youth Studies, 6 (2012): 780-801. doi.org/cd2b.

Kelly, Peter. »Wild and tame zones: Regulating the transitions of youth at risk." Journal of Youth Studies, 2 (1999): 193-211. doi.org/cd2c.

Kogan, Irena in Marge Unt. »Transition from school to work in transition economies.« European Societies, 2 (2006): 219-253. doi.org/d9cnx9.

Kondakci, Yasar in Svena Bedenlier, Olaf Zawacki-Richter. „Social network analysis of international student mobility: Uncovering the rise of regional hubs. " Higher Education 75/3 (2018): 517-535. https:// doi.org/10.1007/s10734-017-0154-9.

Lehmann, Wolfgang. "'For some reason, I get a little scared': Structure, agency, and risk in school-work transitions." Journal of Youth Studies, 4, (2004): 379-396. doi.org/b4w63r.

Lesjak, Dušan in Pornthep Anussornnitisarn. »InternationalisationProfessors' mobility and teaching in foreign languages in Slovenian higher education." International Journal of Innovating and Learning, 22/3 (2017): 340-352. https://doi.org/10.1504/IJIL.2017.086734.

Powell, Justin W. in Claudia Finger. »The Bologna process's model of mobility in Europe: The relationship of its spatial and social dimensions.« European Educational Research Journal, 12/2 (2013): 270-285. https://doi.org/10.2304/eerj.2013.12.2.270.

Schels, Brigitte. »Persistence or transition: Young adults and social benefits in Germany." Journal of Youth Studies, 7 (2013): 881-90o. doi.org/ cd 2 d.

Souto-Otero, Manuel. The SocioEconomic Background of Erasmus Students: A Trend Towards Wider Inclusion? International Review of Education, 54/2 (2008):135-154. DOI: 10.1007/s11159-007-9081-9. 
Teichler, Ulrich in Irina Ferencz, Bernd Wachter. Mapping mobility in European higher education. Volume I: Overview and trends (Vol. 69). Bonn, Germany: Deutscher Akademischer Austausch Dienst, 2011.

Thomson, Rachel in Rebecca Taylor. »Between Cosmopolitanism and the Locals: Mobility as a Resource in the Transition to Adulthood." Young, 13 (2005): 327-342. doi.org/10.1177/1103308805057051.

Van Bouwel, Linda in Reinhilde Veugelers. »The determinants of student mobility in Europe: The quality dimension." European Journal of Higher Education 3/2 (2013): 172-19o. https://doi.org/10.108o/21568235.2013.772345.

\section{Viri}

Evropska komisija (European Commision). (2008). »High level experts discuss future of mobility in EU."Cedefop (European Centre for the Development of Vocational Training), Januar 24, 20o8. Dostop November 9, 2019. https://ec.europa.eu/commission/presscorner/detail/en/IP_o8_85 .

Evropska komisija (2015). »Erasmus - Facts, Figures \& Trends. The European Union support for student and staff exchanges and university cooperation in 2012-13."Luxembourg: Publications Office of the European Union, 2015. Dostop Avgust 11, 2019. https://ec.europa.eu/assets/eac/education/ library/statistics/erasmus-plus-facts-figures_en.pdf.

Mednarodna pisarna, FDV. »Vpisani tuji študenti na izmenjavi.« Ljubljana, Fakulteta za družbene vede, 2018.

Eurostudent VI - Synopsis of Indicators (2016-2018). DZHW - German Center for Higher Education, Research and Science Studies.. Social and Economic Conditions of Student Life in Europe. Dostop Junij 14, 2020. https:// www.eurostudent.eu/download_files/documents/EUROSTUDENT_VI_ Synopsis_of_Indicators.pdf.

Eurostudent VI Database (Data Reporting Module). Dostop Junij 29, 2020. http://database.eurostudent.eu/.

Eurostudent VI Short Report (2016-2018). DZHW - German Center for Higher Education, Research and Science Studies. Dostop Junij 29, 2020. https:// www.eurostudent.eu/download_files/documents/EUROSTUDENT_VI_ short_report.pdf, 18.6.2020.

Evropska Komisija (2017a). Strengthening European Identity through education and culture. The European Commission's contribution to the Leaders'meeting in Gothenburg, 17 November 2017, COM (2017a) 673, 14.11.2017, Strasbourg. 
Evropska Komisija (2017b). Making mobility for all. Dostop Junij 18. 2020. https:/ec.europa.eu/commission/sites/beta-political/files/leaders-workinglunch-mobility_en.pdf

Evropska Komisija (2017c). Erasmus+: Another record year in 2017. Dostop Junij 14, 2020. https://ec.europa.eu/commission/presscorner/detail/en/ IP_19_601.

Evropska Komisija (2018). Predlog Priporočilo Sveta o spodbujanju avtomatičnega vzajemnega priznavanja visokošolskih diplom in srednješolskih spričeval ter izidov iz učnih obdobij v tujini. COM(2018) 27o final 2018/o126 (NLE). Dostop Junij 18. 2020. https://eur-lex.europa.eu/resource.html?uri=cellar:9cf2fee8-5ea7-11e8-ab9c-01aa75ed71a1.0020.02/DOC_1\&format=PDF, 18. 6. 2020 .

Evropska Komisija (2019a). Annual report on intra-EU labour mobility. Luxembourg: Publications Office of the European Union, 2019. Dostop Junij 26, 2020. https://ec.europa.eu/social/main.jsp?catId=738\&langId=sl\&pubId $=8242 \&$ furtherPubs $=$ yes.

Evropska Komisija (2019b). Erasmus+ Higher Education Impact Study. Luxembourg: Publications Office of the European Union, 2019. Publications Office of the EU. Dostop Junij 23. 2020. https:/op.europa.eu/en/publication-detail/-/publication/94d97f5c-7ae2-11e9-9fo5-01aa75ed71a1/language-en.

Evropska Komisija (2019c). Education and Training Monitor 2019. Dostop Junij 17, 2020. https://ec.europa.eu/education/sites/education/files/document-library-docs/volume-1-2019-education-and-training-monitor. pdf.

Evropska Komisija (2020a). Evropski sistem prenašanja in zbiranja kreditnih točk (ECTS). Dostop Junij 17, 2020. https:/ec.europa.eu/education/ resources-and-tools/european-credit-transfer-and-accumulation-system-ects_sl.

Evropska Komisija (2020b). Izobraževanje in usposabljanje. Mobilnost in sodelovanje. Luxembourg: Publications Office of the European Union, 2020. Dostop Junij 23, 2020. https:/ec.europa.eu/education/policies/ higher-education/mobility-and-cooperation_sl.

Evropska Komisija (2020c). Opportunities for Individuals. Dostop Junij 23, 2020. https://ec.europa.eu/programmes/erasmus-plus/opportunities/ overview_en.

Mednarodna pisarna, FDV. „Vpisani tuji študenti na izmenjavi.“ Ljubljana, Fakulteta za družbene vede, 2018.

OECD. (2006). Education st a Glance 2006. Paris. 